\title{
Sağlık Çalışanlarına Uygulanan Şiddet: Özel Bir Tıp Merkezi Örneği ${ }^{1}$
}

\author{
Nesrin AKCA, Ali YILMAZ ve Ŏguz IŞIK \\ Kırlkkale Üniversitesi, Sağllk Bilimleri Fakültesi, Sağllk Yönetimi Bölümü, Kırlkkale \\ nakca@kku.edu.tr
}

\begin{abstract}
Özet
Bu çalışmanın amacı, özel bir sağlık kuruluşunda çalışan personelin şiddet ile karşılaşma sıklığı ve ilişkili etmenlerin belirlenmesidir. Çalışmada veri toplama aracı olarak Arnetz (1998) tarafindan geliştiren "Şiddet Olay Formu" kullanılmıştır. Araştırma sonucunda elde edilen veriler SPSS istatistik paket programına aktarılmış, frekans, yüzde, aritmetik ortalama ve standart sapma gibi tanımlayıcı istatistiksel yöntemlerle analiz edilmiştir. Araştırmanın evrenini, Ankara'da yer alan özel bir sağlık kuruluşunda çalışanların tümü oluşturmaktadır. Araştırma 2012 Mayıs döneminde gerçekleştirilmiştir. Araştırma sonucunda; toplam 92 (\% 81) anket geri dönmüştür. Ankete cevap veren sağlık çalışanlarından \% 24,2'sinin şiddete maruz kaldığı bulunmuştur. Şiddete maruz kalanların \% 28,6'sının $5 \mathrm{kez}$ ve daha fazla şiddete maruz kaldığı; \% 45,5'inin hasta tarafindan şiddet gördüğ̈̈; \% 76,2'lik bir oranla saldırganların çoğunluğunun erkek olduğu ve \% 45,5'lik bir oranla en fazla muayene odasında saldırıya uğradıkları görülmektedir. Şiddete uğrayan personelin tamamı sözel tehdit ya da saldırganlık şeklinde şiddetin türünü açıklamışlardır. Şiddete maruz kalanlarla ilgili hiçbir idari ya da adli işlem yapılmadığı sonucuna ulaşılmıştır.
\end{abstract}

Anahtar Kelimeler: Şiddet, işyeri şiddeti, sağlık çalışanları, çalışma ortamı.

\section{Violence Applied to Health Employees: An Example of a Private Medical Center}

\begin{abstract}
The purpose of this study is determining the factors associated with violence and the incidence of violence of personnel working in the private health institution. In this study "The Violent Incident Form (VIF)" developed by Arnetz (1998) is used as a data collection tool. The data obtained from the research is transferred to the SPSS statistical package program and is analyzed by identifying statistical methods such as frequency, percentage, arithmetic mean and standard deviation. Population of the study is all workers of a private health institution located in Ankara. Research was carried out in the period of May 2012. In the result of the research a total of $92(81 \%)$ questionnaire was returned. The $24.2 \%$ percent of the health workers who responded the questionnaire was found to be exposed to violence. It is found that $28.6 \%$ of the workers was subject to violence 5 times or more; $45.5 \%$ was exposed to violence by patient; the majority of the attackers was males $(76.2 \%)$ and most of the attacks was in the consultant room with the rate of
\end{abstract}

\footnotetext{
${ }^{1}$ Şiddetin Önlenmesi Uluslararası Sempozyumu, 28-29 Haziran 2012, Atatürk Üniversitesi- Erzurum, Sözel Bildiri olarak sunulmuştur.
} 
$45.5 \%$. The workers, exposed to violence, defined the type of violence in case it was verbally or by an attack. It was found that there was neither an administrative nor a legal procedure for the subjects of the violence.

Keywords: Violence, workplace violence, health workers, working environment.

\section{Giriş}

Yıllardır aile içinde, sokakta yaşayanlarda, ceza ve tutukevlerinde varlığ bilinen ve çözümler aranan şiddet olgusu son yıllarda okul, hastane, kamu kuruluşları gibi alanlara da sıçrayarak toplum huzurunu tehdit etmekte ve stres yaratmaktadır (Atan ve Dönmez, 2011). İnsanlık tarihi boyunca var olduğunu söyleyebileceğimiz şiddet kavramı, dar anlamıyla yalnızca fiziksel şiddeti içerir. Genel anlamda şiddet; "aşırı duygu durumunu, bir olgunun yoğunluğunu, sertliğini, kaba ve sert davranışı, beden gücünün kötüye kullanılmasını, bireye ve topluma zarar veren etkinlikleri” kapsar (Köknel, 2006). Sağlık kurumlarındaki şiddet ise "hasta, hasta yakınları ya da diğer herhangi bir bireyden gelen, sağlık çalışanı için risk oluşturan; tehdit davranışı, sözel tehdit, ekonomik istismar, fiziksel saldırı ve cinsel saldırıdan oluşan durum” olarak tanımlanmıştır (Saines, 1999).

Sağlık ortamında hemşire ve sağlık çalışanlarına yönelik şiddet son yıllarda artış göstermektedir. Sağlık kurumunda çalışmak diğer iş yerlerine göre şiddete uğrama yönünden daha risklidir. Sözel şiddetin sıklığı fiziksel şiddetten daha fazladır (Atan ve Dönmez, 2011). Değiş̧ik çalışmalarda, sağlık kurumlarında çalışmanın, diğer iş yerlerine göre şiddete uğrama yönünden 16 kat daha riskli olduğu belirtilmiştir (Elliott, 1997). Şiddetle karşılaşmanın, hekimler kadar diğer sağlık personeli ve hatta hastalar için de ciddi bir sorun olabileceği, hasta ya da yakınlarının değişik nedenlerden kaynaklanan gecikmeleri kabullenemeyip saldırganlaşma eğilimi gösterebileceği belirtilmektedir (Ayrancı ve ark., 2002).

Yapılan çalışmalar sonucunda, sadece yaralanma gibi ciddi olanların şiddet olarak algılandığı ve çok az saldırının kayda alındığ ardından anksiyete ve huzursuzlukta artış gibi psikolojik etkiler ve morarma, ağrı, işitme kaybı, şişlik, burkulma-incinme gibi fiziksel etkiler görülmektedir. Türkiye'de sağlık personelinin mağdur olduğu eylemlere ilişkin yasal düzenlemeler de eksiklikler bulunmaktadır. Hastaneler, sağlık çalışanları için belki de gün geçtikçe tehlikeli ortamlar olmaktadır. Bu durumda hekimler ve sağlık çalışanları kendilerini güvende hissetmemektedirler. Gerek sağlık hizmetindeki hızlı değişimler gerek yasal uygulamalardaki eksiklikler şiddetin önlenmesinde ve çalışan güvenliği sağlama konusunda boşluklar bırakmaktadır (Barrett, 1997; Atan ve Dönmez, 2011; Gates, 1995; Annagür, 2010).

\section{Sağlık Kurumlarında Şiddet}

İşyerinde şiddet ve şiddet tehdidi, hem işyeri personelinin memnuniyetsizliğini hem de organizasyonların yapısını etkileyen önemli bir etkiye sahiptir. İşyeri şiddetinin hizmet ve bakım kalitesinde olumsuz etkileri vardır. Ayrıca şiddet fiziksel veya psikolojik zarar verebilir. Sağlık çalışanlarının değişik boyutlarda şiddete maruz kaldıkları, şiddetin boyutlarının fiziksel şiddetten psikososyal şiddete kadar değişik boyutlarda olduğu söylenebilir (Atan ve Dönmez, 2011). Psikolojik şiddet; taciz, rahatsız etme ve kötü davranış yoluyla herhangi bir kişiye yönelen ve kişiyi iş yaşamından dışlamak amacıyla, kasıtlı olarak yapılan saldırılar olarak tanımlanmaktadır. Psikolojik şiddet, kalıcı psikolojik ve psikosomatik etkiler bırakabilmesi bakımından fiziksel şiddetten daha tehlikeli olabilmektedir (Davenport ve ark., 2003; Westhues, 2002).

Şiddet çeşitli ülke ve kültürlerde de farkl1lık göstermektedir. Örneğin; Amerika'da şiddet acil bir sağlık durumu olarak ilan edilmiştir. Son yıllarda Birleşik Krallık, Avrupa ve Avustralya'nın 
gündemine de taşınmıştır. Avustralya'da şiddetin en ciddi olduğu yer sağlık sektörüdür. Finlandiya'da yapılan bir araştırmaya göre hapishane gardiyanları ve polis memurlarının ardından şiddete maruz kalma sıralamasında psikiyatri hemşireleri 3. sırayı, doktorlar 4. sırayı almışlardır (Atan ve Dönmez, 2011).

Araştırmacılar şiddetin, toplumda ve iş yerlerinde yaygın bir halk sağlığ tehlike olduğunu, iş yeri şiddetinin ve saldırganlığının, günümüzde gittikçe artan bir önem kazandığını belirtmişlerdir. Yine, alınan tüm önlemlere ve önerilere rağmen, yıllardır sağlık alanında çalışan sağlık çalışanlarına karşı şiddetin gittikçe arttığını ve sağlık personelinin şiddet yönünden risk altında olduğunu vurgulamışlardır (Ayrancı ve ark., 2002).

Sağlık kurumlarında, 24 saat kesintisiz hizmet verilmesi, stresli aile üyelerinin varlığ 1 , hastaların uzun süre beklemesi ve bakım hizmetlerinden yeterince yararlanamaması gibi şiddet riskini arttıran değişik faktörler bulunmaktadır. Ayrıca işlerin yoğun fakat personel sayısının az olması, aşırı kalabalık ortamda çalışma, tek başına çalışma, şiddetle baş etme konusunda çalışanın eğitim yetersizliği ve yeterli sayıda güvenlik elemanının olmaması gibi bir takım faktörler de şiddet riskini artıran unsurlar arasında sayılabilir (Çamcı ve Kutlu, 2011).

Sağlık bakım profesyonellerine yönelik şiddetin; ziyaretçiler, çalışma arkadaşları, hastalar ve hasta yakınlarını içeren çok çeşitli kaynakları vardır. Özellikle hasta yakınlarının bir an önce kendileriyle ilgilenilmesini istemesi, kendi hastalarının daha acil olduğunu düşünmeleri, bekleme odalarının düzensiz ve kalabalık olması, hasta ve hasta yakınlarının işlerin düzenli yürümediği veya içeri almada adil davranılmadığı hakkındaki şüphelerinin olması, sağlık çalışanlarının güvenlik ile ilgili işlerle ilgilenmesi risk faktörleri olarak karşımıza çıkmaktadır (Aktuğlu ve Hancı, 1999).

İnsan yaşamının devam ettiği tüm alanlarda olduğu gibi sağlık hizmeti sunulan alanlarda da çeşitli riskler mevcuttur. Bu risklerin önceden tespit edilmesi, gerçekleşmesi durumunda neler yapılması ve risk yönetiminin nasıl sağlanması gerektiğinin belirlenmesi önem arz etmektedir. Bu çerçevede, acil durumları yönetmek için çeşitli araçlara ihtiyaç duyulmuş ve bunlara yönelik bir takım uyarıcı sistemler geliştirilmiştir. Tüm dünyada bu amaçla en yaygın kullanıma sahip olan araçlardan birisi olan renkli kodlar; hastane çalışanlarını haberdar etmekte, risk durumunda iletişime olanak tanımakta, kısa ve net mesaj vermekte, doğru müdahale için zaman kazandırmakta, panik oluşmasına engel olmakta, acil durumlara hazırlıklı olmayı mümkün kılmakta ve hasta ve çalışan güvenliğini sağlamakta kurumlara yardımcı olmaktadır.

Renkli kodların çalışanlar tarafından kabul görmesi ve uygulanmasını sağlamak için belirlenen renk kodlarıyla ilgili eğitimler verilmeli, hastaneyle ilgisi bulunan herkesin haberdar olmasi sağlanmalı ve ortak bir dil oluşturulmalıdır. Türkiye'de Hizmet Kalite Standartları kapsamında 2008 y1lında mavi kod, 2009 yılında pembe kod, 2011 y1l Temmuz ayında ise beyaz kod sisteminin uygulanmaya başlaması ile 3 farklı renkli kod uygulaması başlatılmıştır (Sağlık Bakanlığı, 2013).

Mavi kod; tüm dünyada aynı acil durum için aynı rengin kullanıldığı tek renkli koddur. Genellikle oluşturulan bir çağrı sistemi aracılığıyla sağlik çalışanı tarafından verilen kod, belirlenmiş sorumlu personelin, çoğunlukla kardiyak arrest durumundaki hastaya müdahalesini mümkün kılarken, Pembe kod; hastanede servislerde tedavi için bulunan bebek veya çocuk hastayı kaçırma girişiminin veya kaçırma durumunun tespit edilmesi halinde uygulanan acil durum yönetim aracıdır. Hastane kendi özgün koşulları çerçevesinde çocuk kaçırılma durumları için bir uyarı sistemi kurmaktadır. Beyaz kod ise; hastanelerde çalışanlara yönelik şiddeti önlemeyi amaçlayan acil durum yönetim aracıdır. Kod sisteminin iyi çalışmasında, sistemle ilgili sağlık çalışanlarına eğitimler verilmesi ve kodlara yönelik olarak düzenli tatbikatların yapılması son derece önemlidir. Ayrıca sistemin etkinliği açısından şiddet olayına maruz kalan çalışanlara gerekli desteklerin sağlanması ve gerçekleşen olayların tekrar etmemesi için gerekli düzeltici ve önleyici faaliyetlerin yapılması gerekmektedir. 
Şiddetle başa çıkmak için genel olarak; hasta ve çalışan düzeyinde küçük çaplı önlemler ve hastaneyi ilgilendiren büyük çaplı önlemler olmak üzere başlıca iki ana yöntem bulunmaktadır. Hastaya odaklı önleyici yöntemler arasında; hastayı yakından gözlemlemek, detaylı öykü almak, hastaya yaklaşımda stresle baş etme yollarını öğrenmek, etkili sözel ve sözel olmayan beceriler gibi güncel yaklaşımların yanı sıra kısıtlama, tecrit etme ve ilaçla tedavi gibi geleneksel yöntemler de bulunmaktadır. Hastane geneli ile ilgili geniş çaplı önlemler arasında ise; uygun raporlama sistemleri, etkili güvenlik eğitimleri, güvenlik görevlilerinin insana davranışı ve saldırganlık konusunda eğitilmeleri, 24 saat alan içi güvenlik sağlanması, güvenlikli kapılar, güvenlik kameraları, metal detektörler ve kontrol noktaları, koruyucu akrilik pencere, panik alarmları ve kayıt tutmak sayılabilir (Atan ve Dönmez, 2011).

Ankara'da yer alan özel bir tıp merkezinde çalışan personelin şiddet ile karşılaşma sıklığı ve ilişkili etmenlerin belirlenmesini amaçlayan bu çalışmada; çalışanların şiddete maruz kalma durumları, ne sıklıkta şiddet ya da saldırganlık yaşadıkları, sağlık kuruluşunda en çok kim tarafindan ve nerede şiddet gördükleri, şiddetin türü, çalışanların şiddetle ilgili görüşleri ve şiddet görenlerin davranışları ve aynı zamanda sağlık kuruluşunun bu durum karşısındaki tutumu incelenmiştir.

\section{Yöntem}

\section{Araştırmanın Amacı}

Yapılan bu çalışmada, Ankara'da yer alan özel bir tıp merkezinde çalışan personelin; hasta, hasta yakınları, çalışma arkadaşları ve dışarıdan herhangi biri tarafından uğradıkları şiddet ile karşılaşma sıklığı, maruz kaldıkları şiddetin türü ve ilişkili etmenlerin belirlenmesi amaçlanmıştır. Elde edilen veriler ankete katılan personelin meslek grubu, yaş, cinsiyet ve kurumdaki çalışma sürelerine göre değerlendirilmiştir. Araştırma tanımlayıcı bir çalışma olarak planlanmıştır.

\section{Veri Toplama Aracı}

Çalışanların şiddet ile karşılaşma sıklığı ve ilişkili etmenlerin belirlenebilmesi için Arnetz (1998) tarafından geliştiren "Şiddet Olay Formu (The Violent Incident Form (VIF)" kullanılmıştır. Bu anket, 16 adet sorudan oluşmakta olup; şiddete maruz kalanların tanımlayıcı özelliklerine göre dağılımında; cinsiyet, meslek grubu, çalışma süresi ve yaş olmak üzere dört demografik özelliğe yer verilmiştir. Anketin içeriğinde; çalışanların şiddete maruz kalma durumu ile ilgili görüşlerine yer verilmektedir. Ankete katılanların, bugüne kadar ne sıklıkla şiddete maruz kaldığı, karşılaşılan şiddet olayının türü, kim tarafından saldırganlık veya şiddete maruz kaldığı, saldırganın cinsiyeti, olayın olduğu esnada yalnız çalışıp çalışmadığı, şiddete/saldırıya maruz kaldığı yer, olay karşısında verilen tepki ve sonucunda ne olduğu ve yapılan şiddetin/saldırının olacağını önceden hissedip hissetmediği gibi sorular yer almaktadır. Araştırma sonucunda elde edilen veriler SPSS istatistik paket programına aktarılmış, frekans, yüzde, aritmetik ortalama ve standart sapma gibi tanımlayıcı istatistiksel yöntemlerle analiz edilmiştir.

Araştırmanın evrenini, Ankara'da yer alan özel bir tıp merkezinde çalışanların tümü (sağlık ve idari personel) oluşturmaktadır. Evrenin tümüne $(\mathrm{n}=114)$ ulaşılmak istendiğinden ayrıca örneklem seçilmemiştir. Araştırma 2012 Mayıs döneminde gerçekleştirilmiş ve çalışanların görüşlerinin belirlenebilmesi amacı ile anket yöntemi kullanılmıştır. Araştırma sonucunda; toplam 92 (\% 81) anket geri dönmüştür.

\section{Bulgular ve Tartışma}

Araştırma sonucunda Grafik 1'de de görüldüğü gibi sağlık çalışanlarının \%24,2'sinin şiddete maruz kaldığı; \% 75,8'inin de herhangi bir şiddet görmediği bulgusuna ulaşılmıştır. 


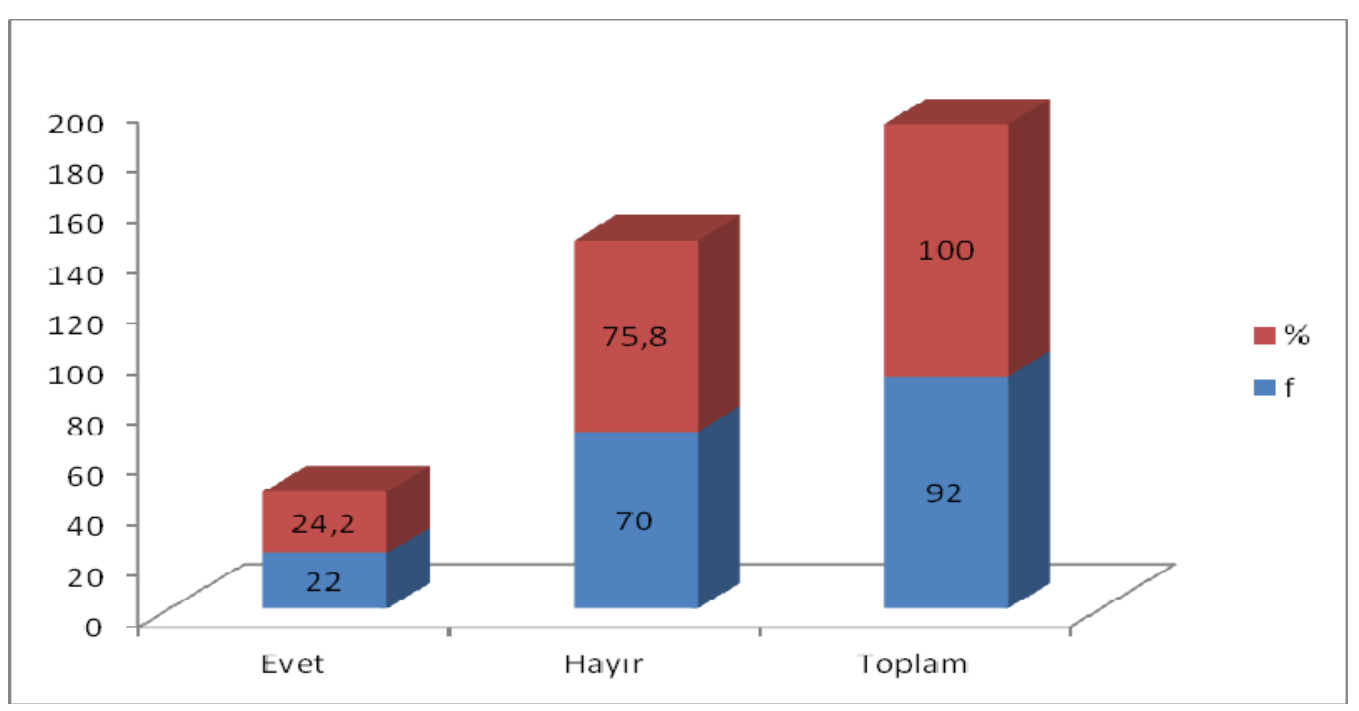

Grafik 1. Çalışanların Şiddete Maruz Kalma Durumu

Tablo 1 incelendiğinde; sağlık çalışanlarının \%76,7'si kadın, \% 23,3'ü erkek; \%35,7'si tıbbi sekreter veya hasta danışmanı, \% 21,4'ü hekim, \% 17,9'u sağlık teknisyeni, \%11,9'u idari personel, \% 8,3'ü hemşire ve \% 4,8'i fizyoterapist olmakla birlikte \% 77,8'i 1-5 yıl arası, \% 22,2'si 5 yılın üzerinde çalışmışıtır. Ayrıca çalışanların \% 51,7'si 30 yaş ve altındayken, \% 23,6'sı 31-39 yaş arası ve 40 yaş ve üzeri sağlık çalışanı yüzdesi ise $\% 24,7$ 'dir.

Tablo 1. Çalışanların Tanımlayıcı Özelliklerine Göre Dă̆ılımı

\begin{tabular}{|l|c|c|}
\hline DEĞiŞKENLER & Sayı & Yüzde \\
\hline Cinsiyet $(\mathbf{n}=\mathbf{9 0})$ & 21 & 23,3 \\
\hline Erkek & 69 & 76,7 \\
\hline Kadın & 18 & 21,4 \\
\hline Mesleğiniz $(\mathbf{n}=\mathbf{8 4})$ & 7 & 8,3 \\
\hline Hekim & 30 & 35,7 \\
\hline Hemşire & 10 & 11,9 \\
\hline Tibbi sekreter / hasta danışmanı & 15 & 17,9 \\
\hline İdari personel & 4 & 4,8 \\
\hline Sağlık Teknisyeni & 70 & 77,8 \\
\hline Fizyoterapist & 70 & 22,2 \\
\hline Çalışma Süresi $(\mathbf{n}=\mathbf{9 0})$ & 20 \\
\hline $1-5$ yıl & 46 & 51,7 \\
\hline$\geq 6$ yll & 21 & 23,6 \\
\hline Yaş $(\mathbf{n}=\mathbf{8 9})$ & 22 & 24,7 \\
\hline$\leq 30$ yaş & \multicolumn{2}{|l}{} \\
\hline $31-39$ yaş &
\end{tabular}

Şiddete maruz kalanların tanımlayıcı özelliklerine (Tablo 2) bakıldığında ise; \%85,7'sinin kadın, \%14,2'sinin erkek; \%47,4'ünün tıbbi sekreter veya hasta danışmanı, \%36,8'inin hekim, \%10,5'inin idari personel ve $\% 5,3$ 'ünün de sağlık teknisyeni olduğu görülmektedir. Tıbbi sekreter veya hasta 
danışmanı olarak görev yapan çalışanlara uygulanan şiddetin en yüksek oranda olması, bu kişilerin hastalarla ilk temas kuran kişiler olmasından kaynaklandığı düşünülmektedir. Kadın çalışanların daha fazla şiddete uğrama sebebi ise, daha savunmasız görünmeleri ya da toplam personel içerisindeki sayılarının daha fazla olmasından kaynaklandığı söylenebilir. Ancak ilgili yazın incelendiğinde, sağlık çalışanları içerisinde erkek sağ lık çalışanlarının $(\% 59,2)$, kadın çalışanlara $(\% 40,8)$ göre daha fazla şiddete maruz kaldıkları da (Eker ve ark., 2011) görülmektedir.

Tablo 2. Şiddete Maruz Kalanların Tanımlayıcı Özelliklerine Göre Dă̆ıllımı

\begin{tabular}{|c|c|c|}
\hline DEĞİŞKENLER & Sayı & Yüzde \\
\hline \multicolumn{3}{|l|}{ Cinsiyet $(\mathrm{n}=\mathbf{2 1})$} \\
\hline Erkek & 3 & 14,2 \\
\hline Kadın & 18 & 85,7 \\
\hline \multicolumn{3}{|l|}{ Mesleğiniz $(n=19)$} \\
\hline Hekim & 7 & 36,8 \\
\hline T1bbi sekreter / hasta danışmanı & 9 & 47,4 \\
\hline İdari personel & 2 & 10,5 \\
\hline Sağllk Teknisyeni & 1 & 5,3 \\
\hline \multicolumn{3}{|l|}{ Çalışma Süresi $(n=21)$} \\
\hline$\leq 5 \mathrm{y} 11$ & 14 & 66,7 \\
\hline$\geq 6$ y1l & 7 & 33,3 \\
\hline \multicolumn{3}{|l|}{ Yaş $(n=20)$} \\
\hline$\leq 30$ yaş & 9 & 45,0 \\
\hline $31-39$ yaş & 5 & 25,0 \\
\hline$\geq 40$ yaş & 6 & 30,0 \\
\hline
\end{tabular}

Saldırıya uğrayan sağlık çalışanlarının çalışma sürelerine göre şiddete uğrama durumları incelendiğinde; şiddet gören çalışanların \%66,7'si 5 yıl ve daha az bir süredir, \%33,3'ü de 5 yıldan daha fazla süredir çalıştıkları görülmektedir. Çalışma süresi ile paralellik gösteren bir diğer değişken de çalışanların yaşlarına göre şiddete uğrama sıklığıdır. Buna göre de, şiddete uğrayan sağlık çalışanlarının \%45'i 30 yaş ve daha altında iken, \%30'u 40 yaş ve üzerindedir. Gerek daha az süre çalışanların gerekse 30 yaş altındakilerin saldırıya uğrama oranlarının daha fazla çıkmasının sebebi olarak; daha tecrübesiz ya da daha savunmasız göründüklerinden kaynaklandığı söylenebilir (Tablo 2). Atan ve Dönmez (2011) tarafindan yapılan çalışmada da benzer sonuçlara ulaşılmıştır.

Tablo 3'e bakıldığında; şiddete maruz kalanların \%28,6'sının 5 kez ve daha fazla, \%33,3'ünün 1 kez, \%19'unun 2 kez ve \%14,3'ünün de 3 kez şiddete maruz kaldığı bulunmuştur. Sağlık çalışanlarına uygulanan şiddetin \%45,5'inin hasta tarafindan, \%40,9'unun da hasta ve hasta yakını tarafindan uygulandığ 1 görülmekte olup; \%76,2'lik bir oranla saldırganların çoğunluğunun erkek olduğu ve $\% 45,5^{\prime}$ lik bir oranla en fazla muayene odasında saldırıya uğradıkları; bunu \%22,7'lik bir oranla koridorun takip ettiği görülmektedir. Bu konuda yapılan çalışmalarda da (Gülalp ve ark., 2009; Annagür, 2010; Ayrancı ve ark., 2002) sağlık çalışanlarına uygulanan şiddetin büyük çoğunluğunun hastane acil servis ve psikiyatri kliniklerinde yaşandığı ifade edilmektedir.

Şiddete uğrayan personelin tamamı sözel tehdit ya da saldırganlık şeklinde şiddetin türünü açıklamışlardır. Şiddetin türü olarak tükürme, 1sırma, tekmeleme, tokat, delici aletle yaralama, itme, sürükleme ya da bir nesne veya tabanca kullanmak gibi ifadelerle karşılaşılmamıştır. Atan ve Dönmez (2011) tarafından yapılan çalışmada da, sözel taciz en fazla cerrahi bilimler kliniklerin de görülürken $(\% 78,8)$, sözel korkutma (\% 59), sözel cinsel taciz $(\% 13,6)$ ve fiziksel saldırı $(\% 22,7)$ en fazla polikliniklerde görülmüştür. 
Şiddete uğrayanların \%36,4’ü olaydan sonra herhangi bir işlem gerekmediğini buna karşıllık \%27,3'ü de kendini savunarak karşıllk verdiğini belirtmişlerdir. \%22,7'si olay karşısında yardım istediğini ifade ederken \%13,6'sı çevredeki kişilerin olayı görüp yardıma geldiğini ifade etmişlerdir. Şiddet gören sağlık çalışanlarının \%30'u olay sonucunda öfkelendiğini, yine \%30'luk ayrı bir grubun da anksiyete yaşadığını, \% 20'si hayal kırıklı̆̆ına uğradığını, \%10'u hiçbir şey hissetmediğini, \%5'i aşağılanmış hissettiğini ve yine ayrı bir \%5'lik grubun ise çaresiz kaldığını açıklamışlardır (Tablo 3).

Tablo 3. Çalışanların Şiddete Maruz Kalma Durumu İle İlgili Görüşleri

\begin{tabular}{|c|c|c|}
\hline İFADELER & Sayı & Yüzde \\
\hline \multicolumn{3}{|c|}{ Bugüne kadar ne sıklıkla şiddete maruz kaldınız? $(\mathrm{n}=21)$} \\
\hline $1 \mathrm{kez}$ & 7 & 33,3 \\
\hline $2 \mathrm{kez}$ & 4 & 19,0 \\
\hline $3 \mathrm{kez}$ & 3 & 14,3 \\
\hline $4 \mathrm{kez}$ & 1 & 4,8 \\
\hline 5 ve daha fazla & 6 & 28,6 \\
\hline \multicolumn{3}{|c|}{ Karşılaşılan şiddet olayının türü $(\mathrm{n}=22)$} \\
\hline Sözel tehdit veya saldırganlık & 22 & 100,0 \\
\hline \multicolumn{3}{|c|}{ Kim tarafından saldırganlık veya şiddete maruz kaldını? $(\mathrm{n}=\mathbf{2 2})$} \\
\hline Hasta & 10 & 45,5 \\
\hline Hasta yakını & 3 & 13,6 \\
\hline Hasta ve hasta yakını & 9 & 40,9 \\
\hline \multicolumn{3}{|l|}{ Saldırganın cinsiyeti $(n=21)$} \\
\hline Erkek & 16 & 76,2 \\
\hline Kadın & 5 & 23,8 \\
\hline \multicolumn{3}{|c|}{ Olayın olduğu esnada yalnız mı çalıșıyordunuz? $(\mathrm{n}=\mathbf{2 2})$} \\
\hline Evet & 11 & 50,0 \\
\hline Hayır & 11 & 50,0 \\
\hline \multicolumn{3}{|c|}{ Saldırıya maruz kaldığınız yer $(n=22)$} \\
\hline Bekleme odas1 & 1 & 4,5 \\
\hline Acil servis & 1 & 4,5 \\
\hline Muayene odası & 10 & 45,5 \\
\hline Koridor & 5 & 22,7 \\
\hline Diğer & 5 & 22,7 \\
\hline \multicolumn{3}{|c|}{ Olay karşısınnda tepkiniz ne oldu? $(n=22)$} \\
\hline Kendimi savunarak karş1lik verdim & 6 & 27,3 \\
\hline Yardım istedim & 5 & 22,7 \\
\hline Diğer kişiler yardıma geldi & 3 & 13,6 \\
\hline Herhangi bir işlem gerekmedi & 8 & 36,4 \\
\hline \multicolumn{3}{|l|}{ Olay sonucunda ne oldu? $(\mathrm{n}=\mathbf{2 0})$} \\
\hline Hiç bir şey olmadı & 2 & 10,0 \\
\hline Öfkelendim & 6 & 30,0 \\
\hline Anksiyete & 6 & 30,0 \\
\hline Aşağılanmış hissettim & 1 & 5,0 \\
\hline Hayal kırıklığı yaşadım & 4 & 20,0 \\
\hline Çaresizlik & 1 & 5,0 \\
\hline \multicolumn{3}{|c|}{ Size karşı bir saldırı olacağını önceden hissettiniz mi? $(n=22)$} \\
\hline Evet & 3 & 13,6 \\
\hline Hayır & 19 & 86,4 \\
\hline
\end{tabular}


Tablo 3. Çalışanların Şiddete Maruz Kalma Durumu İle Illgili Görüşleri (Devamı)

\begin{tabular}{|c|c|c|}
\hline İFADELER & Sayı & Yüzde \\
\hline \multicolumn{3}{|c|}{ Şiddet görmenizin üzerinden ne kadar zaman geçti? $(n=18)$} \\
\hline Bir hafta & 3 & 16,7 \\
\hline Bir ay & 1 & 5,6 \\
\hline 3 ay & 2 & 11,1 \\
\hline 6 ay & 3 & 16,7 \\
\hline $1 \mathrm{y} 1 \mathrm{l}$ & 2 & 11,1 \\
\hline Bir yıldan daha fazla & 7 & 38,9 \\
\hline \multicolumn{3}{|c|}{ Kişinin saldırıda bulunmasını tahminen neye bağlıyorsunuz? $(\mathrm{n}=\mathbf{2 2})$} \\
\hline Ruhsal rahatsızlık & 12 & 54,5 \\
\hline Bilmiyorum & 10 & 45,5 \\
\hline \multicolumn{3}{|c|}{ Olay öncesi hangi faaliyette bulunuyordunuz? $(n=21)$} \\
\hline Muayene / tedavi / fiziksel bakım & 8 & 38,1 \\
\hline Konuşma & 6 & 28,6 \\
\hline Hasta transfer / kaldırma / fiziksel yardım & 1 & 4,8 \\
\hline Etkinlik yok & 1 & 4,8 \\
\hline Hasta tarafindan yapılan talepler & 3 & 14,3 \\
\hline Diğer & 2 & 9,5 \\
\hline \multicolumn{3}{|l|}{ Olay ne zaman meydana geldi? $(\mathrm{n}=20)$} \\
\hline Hastanın kabul işlemlerinin yapıldığı esnada & 5 & 25,0 \\
\hline Muayene / tedavi / fiziksel bakım sırasında & 5 & 25,0 \\
\hline Muayene / tedavi bitiminde & 5 & 25,0 \\
\hline Hasta nakli sırasında & 1 & 5,0 \\
\hline Diğer & 4 & 20,0 \\
\hline
\end{tabular}

Şiddet olayları sağlık çalışanları üzerinde uzun süreli olumsuz etkilere sahiptir. Bunlar; moral düşüklüğü, iş kaybı, memnuniyetsizlik, iş doyumunda azalma, anksiyete, yaşamını tehdit edecek şekilde yaralanma, huzursuzluk, öfke, stres bozukluğu, kabus, uyku sorunları, bitkinlik, sürekli baş ağrıları, kronik ağrı, spazm, kendine güvensizlik, hayal kırıklığı, korku, depresyon, alkol, sigara kullanımı, intihar, fiziksel yaralanma, fiziksel bozukluklar (migren, kusma gibi), özgüvende azalma, mesleğe saygı inancında azalma, kendini suçlama, çaresizlik duygusu, cinsel sorunlar ve kişiler arası ilişkilerde bozulmadır. Atan ve Dönmez (2011) tarafından yapılan çalışmada da, şiddete maruz kalanların \%59'unun öfke, \%47'sinin üzüntü, \%43'ünün hayal kırıklığı ve \%40'1nın korku yaşadığı ve şiddet görenlerin \%15'inin hastayla olmaktan daha az zevk aldığı bulunmuştur.

Araştırma bulgularına göre, şiddete uğrayanların \%38,9'u şiddetin üzerinden 1 yıldan daha fazla süre geçtiğini belirtirken, \%16,7'si de ayrı ayrı şiddetin üzerinden bir hafta veya 6 ay geçtiğini belirtmişlerdir. Saldırıya uğrayanların \%54,5'i saldırganın ruhsal rahatsızlığı olabileceğini tahmin ederken, $\% 45,5$ 'i de herhangi bir tahminde bulunamamıştır. Şiddet görenlerin saldırıdan önce $\% 38,1$ 'i muayene, tedavi ya da fiziksel bakım faaliyetinde bulunduğunu açıklarken, \%28,6's1 da hasta ile konuştuğunu belirtmiştir. Ayrıca \% 14,3'ü hasta tarafından yapılan talepleri değerlendirdiğini, \% 4,8'i hasta transferi veya hastayı kaldırma ya da fiziksek yardım faaliyetinde bulunduğunu ve yine $\% 4,8$ 'lik bir grubun saldırıdan önce herhangi bir faaliyette bulunmadığını ifade etmişlerdir (Tablo 3).

Saldırının ne zaman ortaya çıktığı sorulduğunda; \%25 oranında 3 ayrı cevapla hastanın kabul işlemlerinin yapıldığı esnada, muayene, tedavi veya fiziksel bakım esnasında ya da muayene veya tedavi bitiminde şeklinde cevap vermişlerdir. Şiddet görenlerin \%86,4'ü saldırı olacağını önceden hissetmediğini belirtmiştir. Ayrıca araştırma bulgularına göre, şiddete uğrayan sağlık çalışanlarının 
\%50'si olayın olduğu esnada yalnız çalıştığını, diğer \%50'si de yalnız olmadığını belirtmiştir. Şiddete maruz kalanlarla ilgili hiçbir idari ya da adli işlem yapılmadığı sonucuna ulaşılmıştır (Tablo 3).

\section{Sonuç ve Öneriler}

Sağlık çalışanlarının şiddet ile karşılaşma sıklığı ve ilişkili etmenlerin belirlenmesi amacıyla özel bir tıp merkezinde yapılan bu çalışmada, sağlık çalışanlarının \%24,2'sinin şiddete maruz kaldığ1 bulunmuştur. Şiddet olgusunun, fiziksel ve sözlü saldırılardan suiistimale kadar geniş bir yelpazede değerlendirildiği düşünüldüğ̈̈nde, aşırı bekleme süreleri, aşırı kalabalıklar, iletişim sürecindeki aksaklıklar, sosyal ve kültürel davranışlar da dâhil olmak üzere çeşitli nedenlere bağlı olarak ortaya çıktığı söylenebilir. Bu çalışmada şiddete uğrayan sağlık çalışanlarının oranının konu ile ilgili diğer çalışmalarla karşılaştırıldığında çok yüksek olmaması, araştırmanın özel bir tıp merkezini kapsamasından kaynaklandığı düşünülmektedir. Hastane seçimine etki eden faktörler arasında; hasta hekim ilişkisinin iyi olması, çalışanların kibarlığı, hastane personelinin tutum ve davranışlarının (Tengilimoğlu, 2001) yanı sıra kamu-özel karşılaştırmasında kamunun mecburiyetten, özel hastanelerin ise önceki hizmetten duyulan memnuniyetten olduğu (Taşlıyan ve Gök, 2012) bu düşüncenin oluşmasında etkili olmuştur.

Araştırma sonuçlarına göre şiddete uğrayan sağlık çalışanlarının büyük çoğunluğunun birden fazla şiddete maruz kaldığı görülmektedir. Büyük oranda erkek saldırganlar tarafindan uygulanan şiddetin hastanın kendisi tarafından sözel tehdit veya saldırganlık şeklinde meydana gelmiştir. Araştırmada ilgili yazından farklı olarak şiddet uygulayanların çoğunluğunun hastalar olması, çalışma yapılan kurumun özellik itibariyle fazla komplike vakalara bakmadığı ve hasta profilinin yoğunluklu olarak ayaktan tedavi gerektiren hastalar olduğu düşünülmektedir.

Şiddete uğrayan sağlık çalışanlarının çoğunluğu şiddet olayının sonucunda herhangi bir işlem gerektirmediğini ifade ederken, bazı çalışanlarda kendini savunarak karşıllk verdiklerini ifade etmişlerdir. Ancak bu tür davranışların şiddet olayının türünün değişmesine ve daha ciddi sonuçlara yol açmasına neden olabileceği düşünülmektedir. Bu nedenle şiddet olayının çözümünde taraflardan ziyade önleyici tedbirler başta olmak üzere daha farklı yöntemlerin geliştirilmesinin daha uygun olacağı düşünülmektedir. Şiddetin önlenmesi ile ilgili yapılan araştırmalarda (Ayrancı ve ark., 2002) ise, etkili sağlık kurumu yönetimi ve şiddet konusunu ele alan korunma ve önleme araştırmalarının yapılması, riskli durumun önceden farkına varma ya da başa çıkma gibi sağlık personelinin şiddet konusunda eğitilmesi ile şiddet riskinin azaltılması mümkün olabilmektedir.

Araştırma sonuçlarına göre şiddet olayının büyük oranda muayene odasında ve muayenenin yapıldığı veya hasta kabul işleminin gerçekleştiği anda ve şiddet gören kişinin o esnada tedavi yapmakta veya hastayla konuşmakta olduğu görülmektedir. Sağlık çalışanları ile hasta ve hasta yakınları arasındaki şiddetin öncelikli kaynağının kötü iletişim ve yanlış anlama olduğu (Yıldırım ve ark., 2011) düşünüldüğünde, bu araştırmada da şiddetin oluşmasında iletişim sürecinin etkili olduğu düşünülmektedir. $\mathrm{Bu}$ nedenle sağlık çalışanlarına uygulanan şiddet olaylarının daha da aşağılara çekilebilmesi için; saldırgan davranışla baş etme konularında sağlık bakım personeline gerekli eğitimin verilmesi, bekleme salonlarındaki kalabalığın daha da azaltılması için randevu saatlerinin tam olarak ayarlanması, hasta odalarının ve koridorların çevresel anlamda daha iyi düzenlenmiş olması, yasa koyucuların olması, güvenlik personeli sayısının artırılması, odalarda saldırı anında haber verecek bir alarm sisteminin olması, güvenlikli kapılar ve güvenlik kameralarının olması gereklidir. Ayrıca, sağlık kuruluşlarında şiddet olaylarının kayıtları tutulup, rapor haline dönüştürülmelidir. Böyle bir uygulamayla aynı zamanda yasal prosedürler de yerine getirilmiş olup biraz da olsa şiddetin veya saldırganlığın önüne geçilmiş olacaktır.

Gerek sağlık hizmetindeki hızlı değişimler gerek yasal uygulamalardaki eksiklikler şiddetin önlenmesinde ve çalışan güvenliği sağlama konusunda boşluklar bırakmaktadır. $\mathrm{Bu}$ boşlukları 
gidermek amacıyla son dönemlerde Sağlık Bakanlığı Sağlıkta Kalite ve Akreditasyon Daire Başkanlığı tarafından uygulanmaya başlayan renkli kod sistemine geçiş (beyaz kod) ile birlikte sağlık çalışanlarına uygulanan şiddet olaylarının daha da azalacağı düşünülmektedir. Buna istinaden yöneticilerin üzerine düşeni yapması ve ilgili yasal düzenlemelerin yapılması da şiddetin veya saldırganlığın azaltılması için gereklidir.

\section{Kaynaklar}

Aktuğlu, K., Hancı, H. 1999. Acil Serviste Şiddet Tehdidi. Hekimin Yasal Sorumluluk ve Haklarl (Tip ve Sağllk Hukuku), Ege Üniversitesi Tıp Fakültesi, Toprak Ofset, İzmir.

Annagür, B. 2010. Sağlık Çalışanlarına Yönelik Şiddet: Risk Faktörleri, Etkileri, Değerlendirilmesi ve Önlenmesi, Psikiyatride Güncel Yaklaşımlar, 2(2), ss. 161-173.

Arnetz, J. E. 1998. The Violent Incident Form (VIF): A Practical Instrument for the Registration of Violent Incidents in the Health Care Workplace, Work \& Stress, Vol. 12, No. 1, ss. 17-28.

Atan, Ş. Ü., Dönmez, S. 2011. Hemşirelere Karşı İşyeri Şiddeti, Adli Tip Dergisi, 25 (11), ss. 71-80.

Ayrancı, Ü., Yenilmez, Ç., Günay, Y., Kaptanoğlu, C. 2002. Çeşitli Sağlık Kurumlarında ve Sağlık Meslek Gruplarında Şiddete Uğrama Sıklı̆̆ı, Anadolu Psikiyatri Dergisi, (3), ss. 147-154.

Barrett, S. 1997. Protecting Against Workplace, Public Manag., 79, ss. 9-12.

Çamcı, O., Kutlu, Y. 2011. Kocaeli’nde Sağlık Çalışanlarına Yönelik İşyeri Şiddetinin Belirlenmesi, Psikiyatri Hemşireliği Dergisi, 2(1): ss. 9-16.

Davenport, N., Schwartz, R.D., Elliott G.P. 2003. Mobbing: İşyerinde Duygusal Taciz. Çev. Osman Cem Önertoy, Sistem Yayınc1lık, İstanbul: 5.

Eker, H. H., Topcu, İ., Şahinöz, S., Özder, A., Aydın, H. 2011. “ Bir Eğitim ve Araştırma Hastanesindeki Şiddet Siklı̆̆ı”, Bidder Tip Bilimleri Dergisi, 3(3), ss.16-22.

Elliott, P.P. 1997. Violence in Health Care. What Nurse Managers Need to Know. Nurs Manage; 28(12), ss. 3841.

Gates, D. M. 1995. Workplace Violence. AAOHN J., 43, ss. 536-543.

Gülalp, B., Karcıŏglu, O., Köseoğlu, Z., Sarı, A. 2009. Dangers Faced By Emergency Staff: Experience In Urban Centers In Southern Turkey, Ulus Travma Acil Cerrahi Dergisi, 15, ss. 239-242.

Köknel, Ö. 2006. Bireysel ve Toplumsal Şiddet. 5. Baskı, İstanbul: Altın Yayınları.

Sağlık Bakanlı̆̆ı. 2013. Sağlıkta Ulusal Renkli Kodlara (URK) İlişkin Yeni Düzenleme, http://www.kalite.saglik.gov.tr/content/files/duyurular_2011/2011/07_aralik_2011/0912kalite.pdf (erişim tarihi: 20.01.2013).

Saines, J.C. 1999. Violence and Aggression in A\&E: Recommendations for Action. Accid Emerg Nurs; 7(1), pp. 8-12.

Taşlıyan, M., Gök, S. 2012. Kamu ve Özel Hastanelerde Hasta Memnuniyeti: Kahramanmaraş’ta Bir Alan Çalışması, Kahramanmaraş Sütçü İmam Üniversitesi İktisadi ve İdari Bilimler Fakültesi Dergisi, Sayı:1, ss. 69-94. 
Tengilimoğlu, D. 2001. Hastane Seçimine Etkili Olan Faktörler: Bir Alan Uygulaması, G.Ü. İktisadi ve İdari Bilimler Fakültesi Dergisi, 1, ss. 85-98.

Westhues, K. 2002. A Summary of Research on Mobbing Publihed in OHS Canada. Canada's Occupational Health \& Safety Magazine, pp:30-36.

Yıldırım, H. H., Kalem, M., Seyran, F., Demiray, F. N. 2011., Sağglı İsyeri Ortamında Şiddet: Halkın Şiddet Alglsl ve Değerlendirmeleri Ön Bulgular Raporu, Ankara. 
